\title{
O CERCO DOS CANAVIAIS: CONTRADIÇÕES E CONFLITOS NOS
} ASSENTAMENTOS RURAIS

\section{THE SIEGE OF SUGARCANE: CONTRADICTIONS AND CONFLICTS IN RURAL SETTLEMENTS}

\section{EL SITIO DE LA CAÑA DE AZÚCAR: CONTRADICCIONES Y CONFLICTOS EN LOS ASENTAMIENTOS RURALES}

\author{
Julia Marques Bellacosa ${ }^{1}$ \\ Departamento de Geografia - FFLCH-USP \\ julia.bellacosa@usp.br \\ Martin Hoffmann ${ }^{2}$ \\ Departamento de Geografia - FFLCH-USP \\ martin.hoffmann@usp.br
}

\begin{abstract}
Resumo: O avanço dos canaviais no interior dos assentamentos rurais de São Paulo expõe as contradições do desenvolvimento capitalista no campo ao mesmo tempo em que sinaliza a necessidade de um contínuo debate a respeito da reprodução do campesinato brasileiro. Desde que a cana ingressou oficialmente no assentamento Monte Alegre, situado na região de Araraquara, em uma área de agricultura modernizada, 317 famílias aderiram ao plantio com as usinas - o que corresponde a $89 \%$ de todas as famílias do assentamento. A transformação desses espaços em um "mar" de cana exige uma análise atenta dos rumos pelos quais avança a reforma agrária brasileira. $\mathrm{Na}$ perspectiva de refletir sobre essa questão, apresentamos neste artigo uma análise dos impactos da renda advinda da cana no interior do assentamento.
\end{abstract}

Palavras-chave: campesinato - agrocombustíveis - reforma agrária - assentamento - renda

\begin{abstract}
The advance of sugarcane within the rural settlements of São Paulo exposes the contradictions of capitalist development in the field at the same time it signals the need for a continuing debate about the reproduction of the Brazilian peasantry. Since the cane officially entered the Monte Alegre settlement, in the region of Araraquara, in an area of modernized agriculture, 317 families have joined the planting with plants - which accounts for $89 \%$ of all families of the settlement. The transformation of these spaces in a "sea" of cane requires a careful analysis of the routes by which advances the Brazilian agrarian reform. From the perspective of thinking about this issue, we present in this paper an analysis of the impacts of income from sugar cane within the settlement.
\end{abstract}

Keywords: peasantry - agrofuels - land reform - rural settlement - income

\footnotetext{
${ }^{1}$ Aluna do programa de pós-graduação em Geografia Humana da Universidade de São Paulo.

${ }^{2}$ Aluno do programa de pós-graduação em Geografia Física da Universidade de São Paulo.
} 
Resumen: El avance de la caña de azúcar dentro de los asentamientos rurales de São Paulo expone las contradicciones del desarrollo capitalista en el campo, al mismo tiempo que señala la necesidad de un continuo debate acerca de la reproducción del campesinado brasileño. Desde la caña entró oficialmente en el asentamiento de Monte Alegre, en la región de Araraquara, en un área de la agricultura modernizada, 317 familias se han unido a la siembra de plantas - que representa el $89 \%$ de todas las familias del asentamiento. La transformación de estos espacios en un "mar" de la caña requiere de un cuidadoso análisis de las rutas por las que los avances de la reforma agraria brasileña. Desde la perspectiva de pensar sobre este tema, presentamos en este trabajo un análisis de los impactos de los ingresos procedentes de la caña de azúcar dentro del asentamiento.

Palabras Clave: los campesinos - los agrocombustibles - reforma agraria - asentamiento rural - ingresos

\section{Introdução}

A discussão da questão agrária não pode prescindir do debate da resistência camponesa em pleno século XXI. Se de um lado estão aqueles que usam a terra para extrair renda e lucro, do outro se encontram os camponeses cujo objetivo é a reprodução do grupo familiar. A vida camponesa não é organizada pelas necessidades do mercado, ela está assentada na forma simples de circulação de mercadoria, movimento expresso na fórmula M-D-M, em que mercadoria é convertida em dinheiro para comprar mercadoria, em oposição à produção capitalista em que dinheiro é convertido em mercadoria para novamente compor dinheiro, representado pela fórmula D-M-D (OLIVEIRA, 1986, p.68).

A compreensão de que o campesinato está fadado ao desaparecimento imperou tanto na tradição dos estudos marxistas como entre os neoliberais, apoiado em análises que demonstravam a inviabilidade econômica da unidade de produção camponesa. Assim, contraditoriamente, a teoria da descamponização aproximou campos distintos, ou seja, teóricos com uma práxis voltada para a transformação social rumo ao socialismo, acabam convergindo com os neoliberais defensores de um mundo onde a agricultura é um ramo da indústria submetido à taxa média de lucro (PAULINO; ALMEIDA, 2010, p.55).

O fato é que o campesinato permanece vivo e tem lutado por sua reprodução, seja na luta pela terra, na constituição de assentamentos rurais, seja na formação de cooperativas de trabalho, ou mesmo através da sujeição de sua renda ao capital. 
A recriação do campesinato é parte contraditória do modo de produção capitalista, uma vez que o desenvolvimento do capitalismo no campo ocorre de modo desigual e contraditório, isto é, o avanço do capitalismo no campo não se faz em sua totalidade:

"Seria o próprio modo capitalista de produção dominante que geraria relações capitalistas de produção e relações não-capitalistas de produção, combinadas ou não, em função do processo contraditório intrínseco a esse movimento (desenvolvimento)." (OLIVEIRA, 1990, p.46)

Portanto, ao mesmo tempo em que o capitalismo avança reproduzindo relações tipicamente capitalistas, ele também recria relações não capitalistas. É principalmente a relação social advinda do trabalho familiar que define a propriedade camponesa, cuja reprodução é realizada sobre pilares diferentes das bases capitalistas, ou seja, através de relações não especificamente capitalistas.

O atual estágio de desenvolvimento do capitalismo, marcado por intensas mudanças desencadeadas pelo processo de mundialização do capital, traz fortes consequências para as populações camponesas. Inserido neste contexto está a crescente utilização de mecanismos de integração e subordinação da produção camponesa aos complexos agroindustriais. Dessa forma, a presença maciça de cana-de-açúcar nos assentamentos rurais de reforma agrária de São Paulo impõe novos desafios para repensar o campesinato brasileiro, cuja economia capitalista internacionalizada estabelece novos desdobramentos nas relações sociais no campo.

Quais são as implicações da expansão dos agrocombustíveis para o processo de reprodução camponesa? A inserção do camponês no universo das usinas revela indícios de descamponização? Ou trata-se de estratégias de resistência do camponês na terra - um negar-se para continuar sendo aquilo que nunca deixaram de ser? A partir dessas questões, que permeiam as novas transformações do campo brasileiro, vamos analisar a situação vivenciada pelos moradores do assentamento Monte Alegre, sob o olhar dos impactos da cana-de-açúcar no interior desses espaços de reforma agrária. 


\section{A Fazenda Monte Alegre}

O assentamento Monte Alegre (Mapa 1) está situado na região central do Estado de São Paulo, entre os municípios de Araraquara, composto por 208.725 habitantes, e Motuca $^{3}$, com apenas 4.290 habitantes.

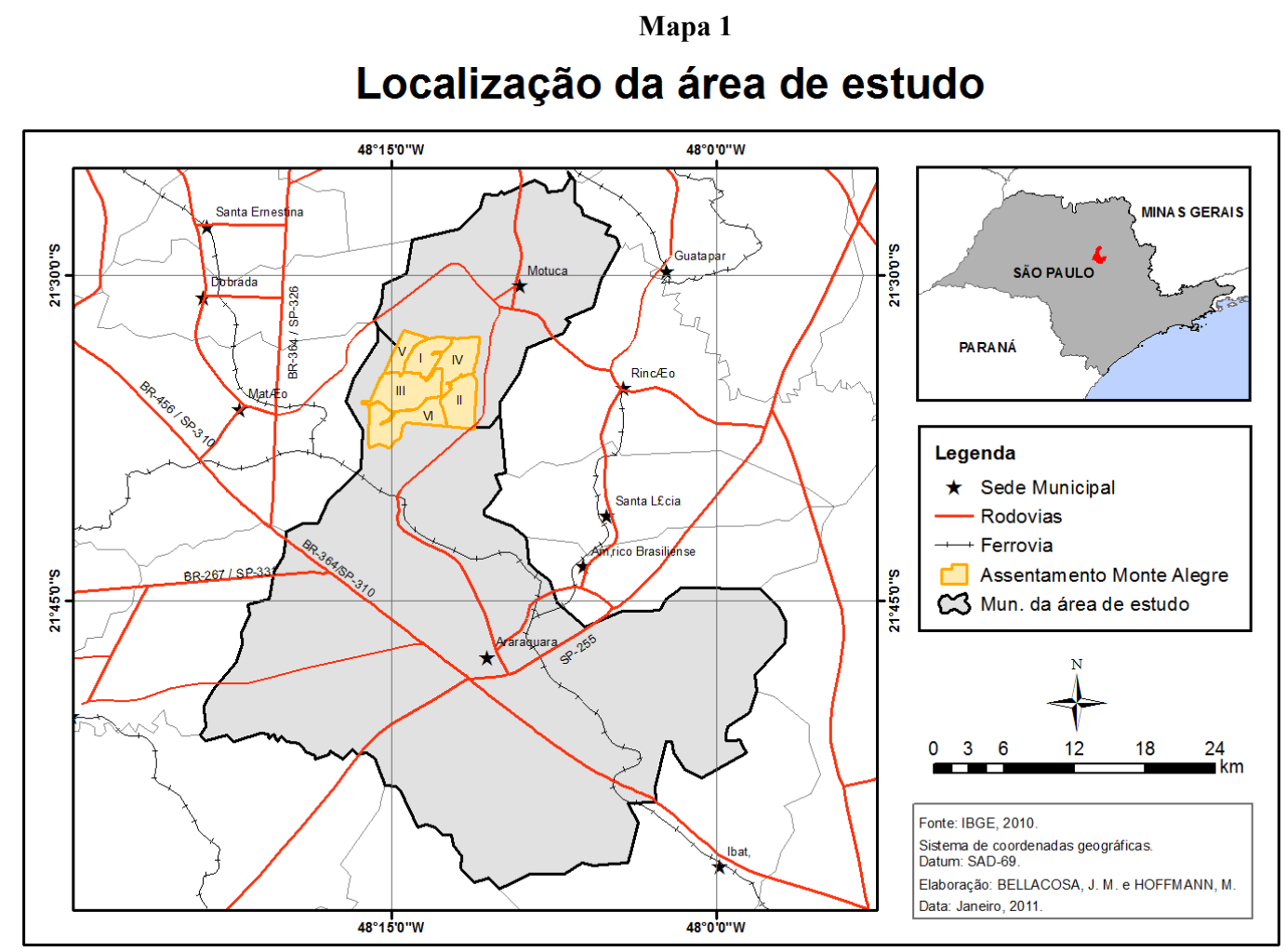

Ambos os municípios estão inseridos na Região Administrativa de Araraquara, conhecida por integrar a Região de Ribeirão Preto, também chamada "Califórnia Brasileira" - uma área de agricultura modernizada, onde se destacam a cana-de-açúcar e a laranja.

Atualmente o assentamento Monte Alegre é constituído por seis núcleos formados entre 1985 e 1997, que representam um total de 358 lotes, correspondente a uma área de 5.101 hectares, sendo 4.960 hectares de área agrícola, conforme Tabela . Os núcleos III e

\footnotetext{
${ }^{3}$ O município de Motuca foi constituído somente em 1990, quando foi emancipado de Araraquara.
} 
VI pertencem ao município de Araraquara enquanto o restante - núcleos I, II, IV e V, a Motuca.

Tabela 1 - Núcleos do Assentamento Monte Alegre

\begin{tabular}{|c|c|c|c|c|c|c|}
\hline Município & $\begin{array}{c}\text { Projeto de } \\
\text { Assentamento }\end{array}$ & Início & $\begin{array}{r}\text { Domínio } \\
\text { da Terra }\end{array}$ & $\begin{array}{l}\text { No. De } \\
\text { Lotes }\end{array}$ & $\begin{array}{c}\text { Área } \\
\text { Total } \\
\text { (ha) }\end{array}$ & $\begin{array}{c}\text { Área } \\
\text { Agrícola } \\
\text { (ha) }\end{array}$ \\
\hline Motuca & $\begin{array}{c}\text { Monte Alegre } \\
1\end{array}$ & $\mathrm{mai} / 85$ & Estadual & 49 & 726 & 684 \\
\hline Motuca & $\begin{array}{c}\text { Monte Alegre } \\
2 \\
\end{array}$ & out $/ 85$ & Estadual & 62 & 858 & 858 \\
\hline Araraquara & $\begin{array}{c}\text { Monte Alegre } \\
3\end{array}$ & ago/86 & Estadual & 76 & 1.100 & 1.036 \\
\hline Motuca & $\begin{array}{c}\text { Monte Alegre } \\
4\end{array}$ & ago/86 & Estadual & 49 & 679 & 679 \\
\hline Motuca & $\begin{array}{l}\text { Monte Alegre } \\
5\end{array}$ & out/91 & Estadual & 34 & 484 & 451 \\
\hline Araraquara & $\begin{array}{c}\text { Monte Alegre } \\
6 \\
\end{array}$ & mai/97 & Estadual & 88 & 1.254 & 1.252 \\
\hline \multicolumn{4}{|r|}{ Total } & 358 & 5.101 & 4.960 \\
\hline
\end{tabular}

Fonte: ITESP, 2010. Org. BELLACOSA, Julia.

Cada família possui em média 14 hectares de terras no lote agrícola e nos casos dos núcleos com agrovila o acréscimo de mais 1 hectare de terra.

\section{$O$ ingresso da cana nos assentamentos rurais}

O capital não transforma de uma só vez todas as formas de produção ditadas pelo lucro capitalista, e abre espaço para a expansão do trabalho familiar nas suas múltiplas formas, como camponês proprietário, parceiro, rendeiro ou posseiro. Isso ocorre porque o trabalho camponês ora é um obstáculo, ora pode ser vantajoso ao capitalista. Neste sentido, o processo de reprodução do campesinato no cerne do desenvolvimento capitalista atual, sinaliza um dos caminhos para desvendar as transformações recentes do campo brasileiro.

Dessa forma, o processo de reprodução do capital não é totalmente produzido por relações tipicamente capitalistas - o que permite que o campesinato fique sujeito ao capital, sem que seja expulso da terra, sem que ocorra a expropriação dos seus instrumentos de 
trabalho. Segundo Ariovaldo Umbelino de Oliveira (1999, p.106), esse processo contraditório revela que o capital monopoliza o território sem, entretanto, territorizalizar-se. Trata-se do processo de monopolização do território pelo capital monopolista e, nesse caso, a produção fica subordinada à circulação.

$\mathrm{O}$ ingresso da cana no assentamento Monte Alegre alinha-se a esse processo. A pressão cada vez maior das usinas da região, o interesse do poder público local, representado pelo prefeito de Motuca, a ausência de eficientes políticas públicas, entre outros, propiciaram a entrada da cana no assentamento a partir de 2002. É neste contexto que é promulgado pelo Instituto de Terras do Estado de São Paulo - ITESP - órgão gestor do Monte Alegre - a portaria $\mathrm{n}^{0} 75$ de 24/10/2002, revogada posteriormente pela Portaria ${ }^{0}$ 77 de 27/07/2004, como forma de viabilizar, por meios oficiais, a "parceria" ${ }^{4}$ entre a agroindústria e os assentados - atividade que já estava sendo realizada em alguns lotes.

Inicialmente, o acordo firmado entre a usina Santa Luiza e os assentados estabeleceu que tanto a produção quanto o corte da cana deveria ser realizado sob o regime de mutirão. Esse regime, assim como a troca pura e simples de dias de trabalho entre os assentados, são práticas tradicionais camponesas de ajuda mútua, empregadas para suprir, em determinados momentos, a força de trabalho familiar. Esse processo tende a aparecer em função de os camponeses não disporem de rendimentos monetários necessários para pagar trabalhadores assalariados (OLIVEIRA, 1990, p.56).

Dessa forma, a usina ficaria responsável por fornecer as mudas, tecnologia do plantio, adubos e insumos, processamento e compromisso de compra das matérias-primas, enquanto os assentados deveriam se incumbir do restante, que incluía o plantio, os tratos culturais, o corte, e até o transporte da cana junto à usina. As atividades de preparação do cultivo eram disponibilizadas apenas na primeira safra e descontadas em tonelagem: 50\% na primeira colheita, $30 \%$ na segunda, e $20 \%$ na terceira.

Logo no primeiro ano começou haver um descontentamento por parte de alguns assentados frente ao regime de mutirão, desencadeado pela desigualdade no esforço e na

\footnotetext{
${ }^{4} \mathrm{O}$ termo parceria foi criado pelos órgãos gestores para designar contratos entre assentados e usinas, envolvendo a permissão e expansão da cana nos assentamentos rurais - legalizada pelo ITESP, através da portaria de 24/10/2002, proibida pelo INCRA sob o argumento de contrariar o princípio da Reforma Agrária (FERRANTE, 2007). Apesar da utilização do termo, há uma assimetria nas relações de poder entre os dois contratantes, e conforme veremos a seguir, os assentados encontram-se na maioria das vezes em relação de subordinação frente às Usinas.
} 
quantidade de cana cortada por cada um. Segundo Teresinha D’Aquino (1996, p.8), mesmo para aqueles que aceitam a organização em cooperativa, a grande dificuldade da questão do trabalho coletivo num entorno capitalista parece ser o controle das horas trabalhadas e as diferenças de produtividade, em especial as relativas às diferenciações próprias do ciclo vital e do gênero.

Os que acabaram cortando uma grande quantidade de cana se sentiram prejudicados frente aos que tiveram um rendimento inferior, e essa insatisfação culminou na descaracterização do mutirão e no repasse, ao longo das safras, das tarefas do plantio e corte às usinas - fato já previsto em contrato firmado entre a usina e os assentados ${ }^{5}$ :

"Caso o(s) FORNECEDOR(ES) não possuam de imediato todos os subsídios técnicos, mecânicos e financeiros, necessários para implementação da referida cultura, a RECEBEDORA poderá efetuá-los, total ou parcialmente, inclusive com o fornecimento de mudas, adubos, herbicidas, adubo verde antes do plantio e todos os demais serviços de plantio das canas, tais como: preparo do solo, aplicação de calcário, sulcação, corte e transporte das mudas, plantio, cobrição, recobrição, aplicação de adubos e herbicidas e quebra de lombo, nas épocas oportunas e de acordo com as técnicas apropriadas para tal cultura, sendo que pela quebra de lombo, nas épocas oportunas e de acordo com as técnicas apropriadas para tal cultura, sendo que pela prestação desses serviços, será(ão) cobrado(s) do(s) FORNECEDOR(ES) os preços usuais e praticados junto aos demais fornecedores, de acordo com a tabela anexa."

De acordo com o contrato firmado entre a usina Santa Luiza e os assentados, a cobrança pelos serviços de corte, carregamento, e transporte da cana deveria ser feito de uma só vez após o período de colheita, em que são descontados 35\% do total da produção. Desse montante: o corte seria responsável por $19,90 \%$, o carregamento por $4,02 \%$ e o transporte por $11,08 \%$.

Conforme citamos anteriormente, o camponês que opta por delegar à usina a tarefa do plantio e fornecimento de todos os insumos necessários para o cultivo recebe os descontos em tonelagem: $50 \%$ na primeira colheita, 30\% na segunda e 20\% na terceira. Já aquele que transfere para o comando da usina também as tarefas do corte, carregamento, e transporte, recebe ainda o desconto de $35 \%$ sobre valor total da produção. Esse fato sinaliza a apropriação de uma parcela cada vez maior da renda camponesa pelas usinas e o

\footnotetext{
${ }^{5}$ Contrato firmado entre a usina Santa Luiza e assentado do Monte Alegre II. Compromisso particular de plantio, cultivo e fornecimento de cana-de-açúcar safras 2008 a 2012.
} 
fortalecimento da lógica da agricultura capitalista nos espaços de reforma agrária. Ao transferir todo o trabalho para a usina, o camponês passa a participar do processo agrícola apenas com a condição de proprietário da terra, cuja prática configura-se em arrendamento.

Outra questão refere-se à socialização do camponês no interior do processo produtivo, que segundo Oliveira (1990, p.60) é um importante elemento da produção camponesa, pois é através dela que as crianças são iniciadas como personagens da divisão social do trabalho no interior da unidade produtiva. Se a cana quase não requer trabalho na terra, seu cultivo seria um fator propulsor da "expulsão" dos jovens do assentamento, já que não há trabalho no lote?

Até os que falam com reservas do ingresso da cana no assentamento, afirmam que o cultivo trouxe muitos benefícios à população local, e inclusive alterou o padrão de vida de muitos assentados, conforme expresso na fala:

"Olha, se não fosse a cana eu estava enterrado aqui, foi uma salvação. Eu consegui pagar todas minhas dívidas no banco. Graças a Deus com a cana eu consegui quitar tudo, se não fosse isso, eu teria mais uns 12 anos pra pagar."(Vanderlei, Monte Alegre II)

Segundo Vanderlei, a cana permitiu que ele se livrasse do endividamento bancário fato que vai corroborar para que ele consiga obter financiamento junto às instituições financeiras, para futuros cultivos.

Questões pertinentes, como a descaracterização do trabalho familiar - condição mínima para a permanência nos assentamentos - foram profundamente afetadas pela entrada da cana e do capital produtivo da usina em terras de reforma agrária (FERRANTE e AMARAL, 2007, p.111).

Entretanto, ao permitir o pagamento das dívidas, a cana pode ter possibilitado ao assentado investir em outras atividades, antes paralisadas, por falta de financiamento. Neste sentido, a monocultura canavieira, que ameaça a autonomia camponesa, a continuidade do trabalho familiar e a sociabilização no interior do processo produtivo, pode ter representado, contraditoriamente, a permanência do camponês na terra, a possibilidade da realização de novos cultivos, favorecendo a sociabilização dentro do assentamento?

Quais foram os reais impactos da presença da cana no assentamento Monte Alegre? O que foi feito com a renda advinda dessa atividade? Estas e outras questões serão 
analisadas a seguir, onde é feito um balanço, principalmente socioeconômico, do cultivo da cana no assentamento.

\section{A renda da cana em números}

Demonstramos a seguir um balanço quantitativo dos impactos da produção canavieira no assentamento Monte Alegre. Os dados foram obtidos junto ao ITESP, e após serem digitalizados, foram minuciosamente trabalhados para gerarem tabelas e gráficos, que poderão ser visualizados na sequência.

Como podemos observar no

Gráfico 1 o número de famílias que aderiram ao projeto "cana" foi crescendo ao longo do tempo. Em 2004, 40 famílias iniciaram o plantio de cana no assentamento. No ano seguinte esse número saltou para 96 famílias, e na safra 2009/2010 atingiu o recorde: 284 famílias ingressaram na "parceria", o que representou 79\% das famílias do Monte Alegre. Já na safra 2010/2011, ocorre uma pequena redução de produtores de cana no assentamento, devido ao período de renovação dos canaviais em alguns lotes.

\section{Gráfico 1 - Número de lotes produtores}

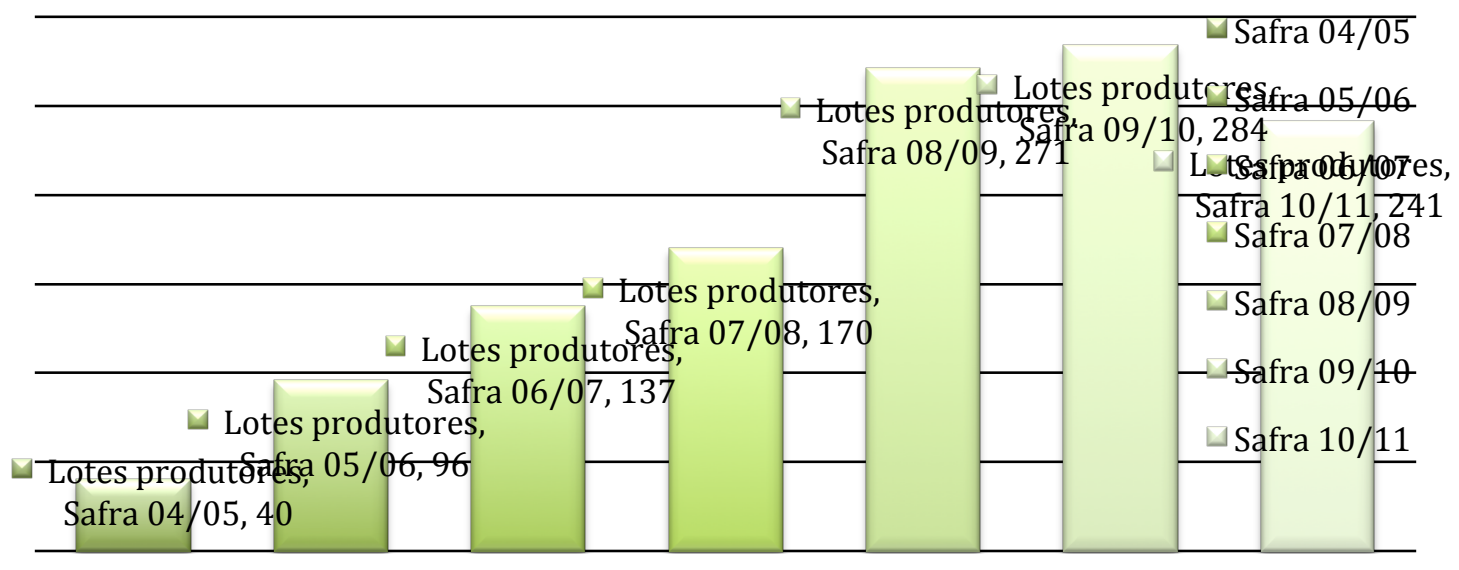

Fonte: ITESP, 2011. Org. BELLACOSA, Julia.

O gráfico indica o crescimento vertiginoso de produtores de cana no assentamento Monte Alegre - o que sinaliza uma grande aceitação do projeto cana pelos assentados. 
A área utilizada para produção de cana de açúcar, conforme

Gráfico 2, saltou de 229,59 hectares, o equivalente a 5\% da área total agricultável do assentamento, para 1777,44 hectares na safra 2009/2010, que representa $36 \%$ de toda a área de cultivo do Monte Alegre, seguido de 1487,78 em 2011 - 30\% de toda área agricultável do assentamento. A cana-de-açúcar passa a vigorar nas terras do Monte Alegre, seguida pelas produções em escala bem mais reduzida de milho, mandioca, feijão, manga, alface, entre outras.

Gráfico 2 - Área utilizada para produção de cana de açúcar no assentamento Monte Alegre

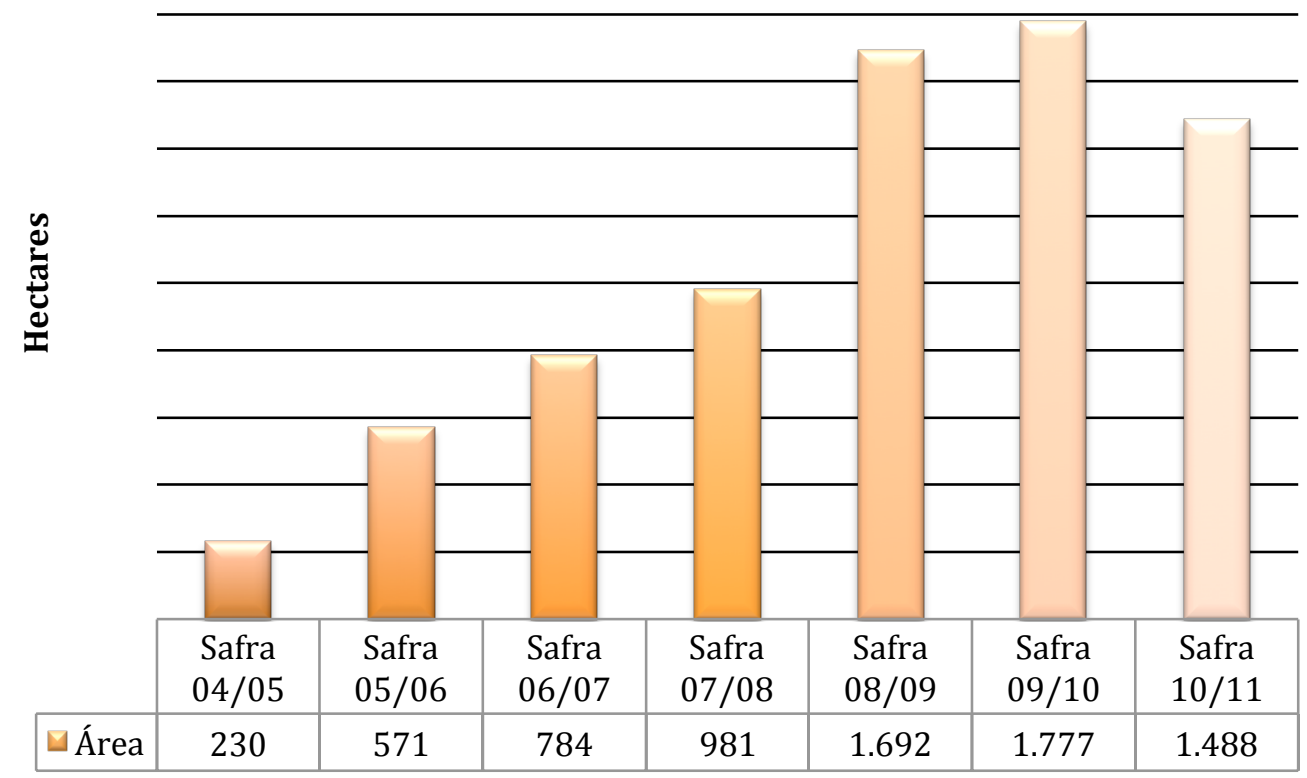

Fonte: ITESP, 2011. Org. BELLACOSA, Julia.

O número sobre o cultivo da cana é ainda mais expressivo quando analisamos o número total de famílias que aderiram ao projeto nesses últimos sete anos. Para termos uma idéia, desde que a "parceria" para o plantio de cana começou no assentamento $89 \%$ das famílias ingressaram no projeto em algum período dessas sete safras. Significa dizer que somente 41 famílias, de um total de 358 , optaram por não produzir cana até a safra 2010/2011.

O assentamento Monte Alegre transformou-se, de fato, em um mar de cana, principalmente se levarmos em conta que a legislação vigente determina o limite de $50 \%$ do 
plantio de cana por lote, o que impossibilita que este cultivo obtenha contornos ainda mais expressivos.

Desde que a cana adentrou no assentamento, nenhum outro cultivo foi cultivado nessas proporções. Ao que se deve o sucesso de tamanha adesão? Muitos assentados, cuja postura crítica acenava contra esta "parceria" junto às usinas, acabaram aderindo ao projeto - o que serviu para engrossar as estatísticas do triunfo da monocultura neste espaço de reforma agrária. A expansão da cana no interior do assentamento está atrelada, sobretudo, à renda auferida com essa produção - a qual será analisada a seguir.

A renda que vamos analisar na sequência é referente à metade do sítio, ou em alguns casos a uma porção inferior a $50 \%$ da área total. Para termos um parâmetro: mais de $40 \%$ das famílias do Monte Alegre iniciaram o plantio de cana em 50\% do lote durante a safra 2004/2005. O restante plantou cana em área inferior à permitida pela legislação.

Ao longo das sete safras, o número de famílias que cultivaram cana em 50\% do lote aumentou e ultrapassou 60\% do total na safra 2009/2010, conforme Gráfico 3.

Gráfico 3 - Porcentagem da área plantada de cana

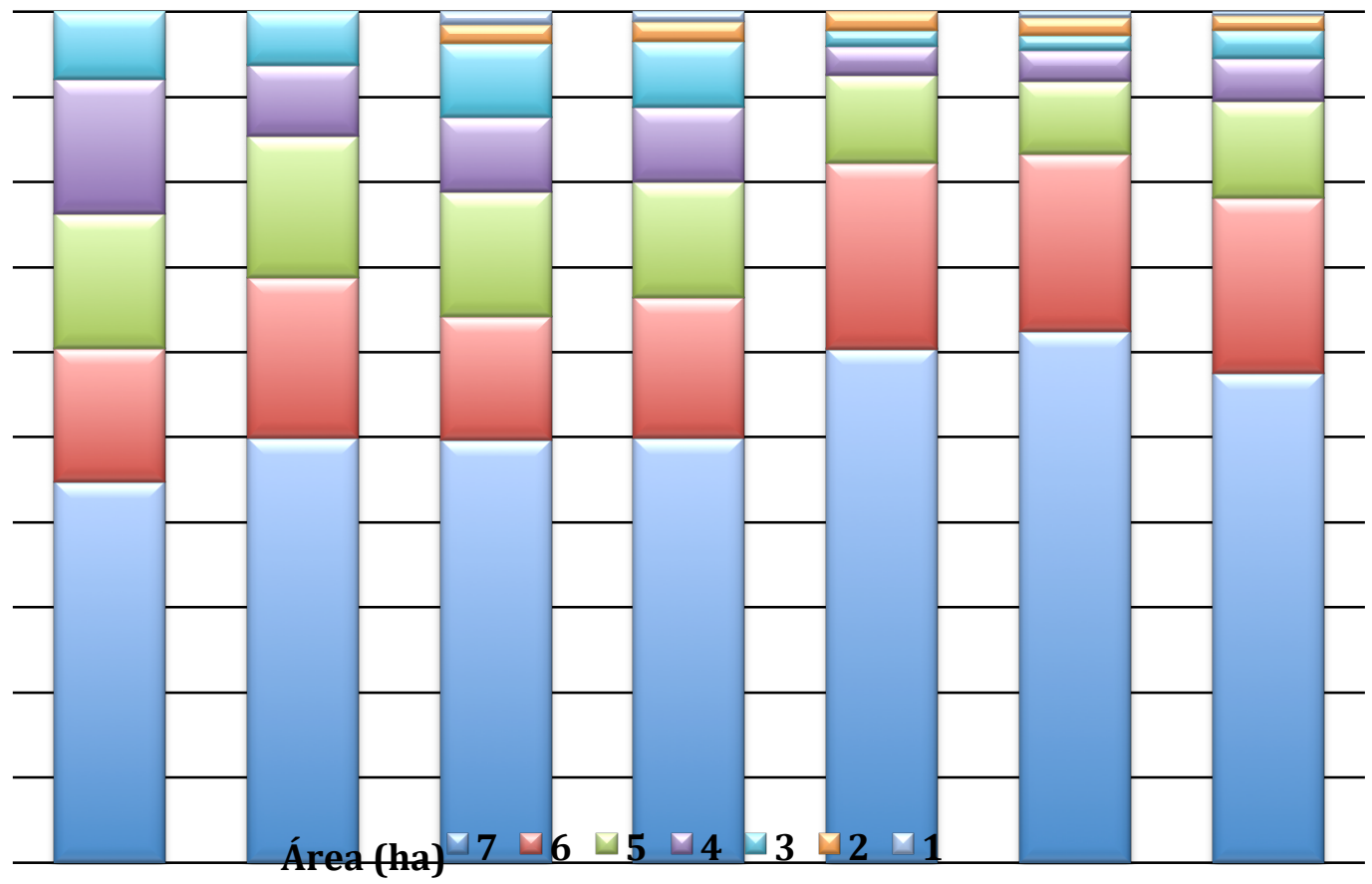

Fonte: ITESP, 2011. Org. BELLACOSA, Julia. 
De acordo com o

Gráfico 4, na primeira safra (2004/2005) a renda líquida média obtida por família foi de $\mathrm{R} \$ 17.081$, o equivalente a $\mathrm{R} \$ 1.423$ mensais. No ano seguinte, esse número se elevou para R\$20.622. Nas safras subsequentes o número variou na casa dos R\$ 14.000 e R\$ 11.000, alcançando na safra 2010/2011 seu pior desempenho: R\$ 10.863.

\section{Gráfico 4 - Média da renda total líquida no assentamento Monte Alegre}

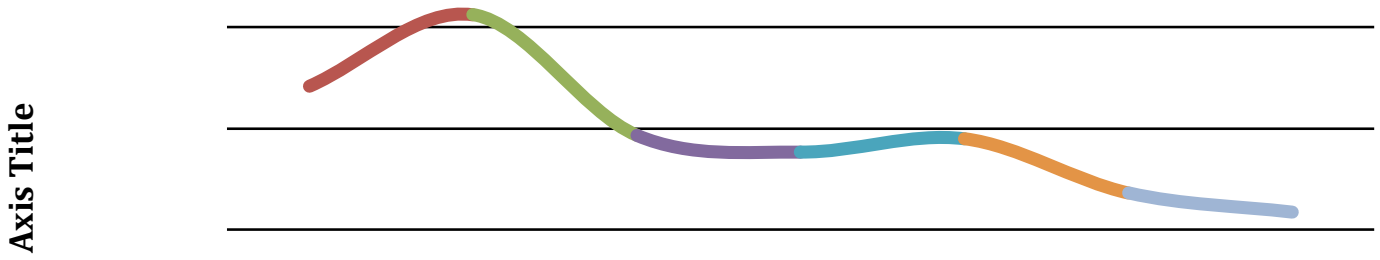

\begin{tabular}{|c|c|c|c|c|c|c|c|}
\cline { 2 - 7 } \multicolumn{1}{c|}{} & Safra & Safra & Safra & Safra & Safra & Safra & Safra \\
& $04 / 05$ & $05 / 06$ & $06 / 07$ & $07 / 08$ & $08 / 09$ & $09 / 10$ & $10 / 11$ \\
\hline Média & $\mathrm{R} \$ 17.081$ & $\mathrm{R} \$ 20.622$ & $\mathrm{R} \$ 14.664$ & $\mathrm{R} \$ 13.830$ & $\mathrm{R} \$ 14.489$ & $\mathrm{R} \$ 11.807$ & $\mathrm{R} \$ 10.863$ \\
\hline
\end{tabular}

Fonte: ITESP, 2011. Org. BELLACOSA, Julia.

A renda total líquida refere-se ao valor total pago aos assentados, já descontados os investimentos realizados no plantio pelas usinas. A partir do segundo ano de safra, para a manutenção da lavoura (tratos culturais), cada produtor utilizou a renda obtida na cana.

$\mathrm{O}$ que representou essa renda para as famílias do Monte Alegre? O que significou receber R\$ 14.000, R\$ 17.000, R\$ 20.000 por ano? É um valor significativo? Eles recebiam uma renda média semelhante com a produção de outros cultivos?

Ao percorrer os lotes do assentamento Monte Alegre, observamos que os assentados consideram, de forma unânime, a renda obtida através da cana elevada, conforme trecho extraído da conversa com Sr. Artur:

“A cana dá bastante dinheiro. A primeira vez eu recebi R\$ 14.000 e as outras vezes foi diminuindo, porque a cana vai diminuindo, R\$13.000 e depois tinham as parcelas de $\mathrm{R} \$ 1000, \mathrm{R} \$ 800 \ldots$ Dá para o pessoal viver 
bem. Eu acredito que aqui o que deu mais lucro até hoje foi a cana." (Sr.Artur, núcleo I).

A renda obtida com a cana representou para muitas famílias uma elevada quantia financeira - a maior que já tiveram ao longo das diversas experiências agrícolas, conforme fala de Moisés:

\begin{abstract}
“A gente plantava grão, só grão, porque eu também era contra o plantio de cana. A gente plantava soja, milho, feijão, amendoim. No primeiro ano que a gente plantou amendoim aqui, não conseguimos tirar nem para $o$ gasto, milho dava naquelas manchinhas onde a terra ficava mais estercada, mais cinza, então o resto era tudo cabeça de maritaca. A terra era fraquíssima mesmo. O que produziu melhor na época foi o arroz, porque ele não exige terra muito forte. Nos primeiros anos ele produziu até bem, depois foi caindo, caindo...” (Moises, núcleo I)
\end{abstract}

Do ponto de vista econômico, conforme os dados apresentados, a cana foi um projeto que apresentou êxito. Para termos uma ideia sobre a variação de renda adquirida por cada família, apresentamos o Gráfico 5 a seguir:

Gráfico 5 - Renda total líquida - assentamento Monte Alegre

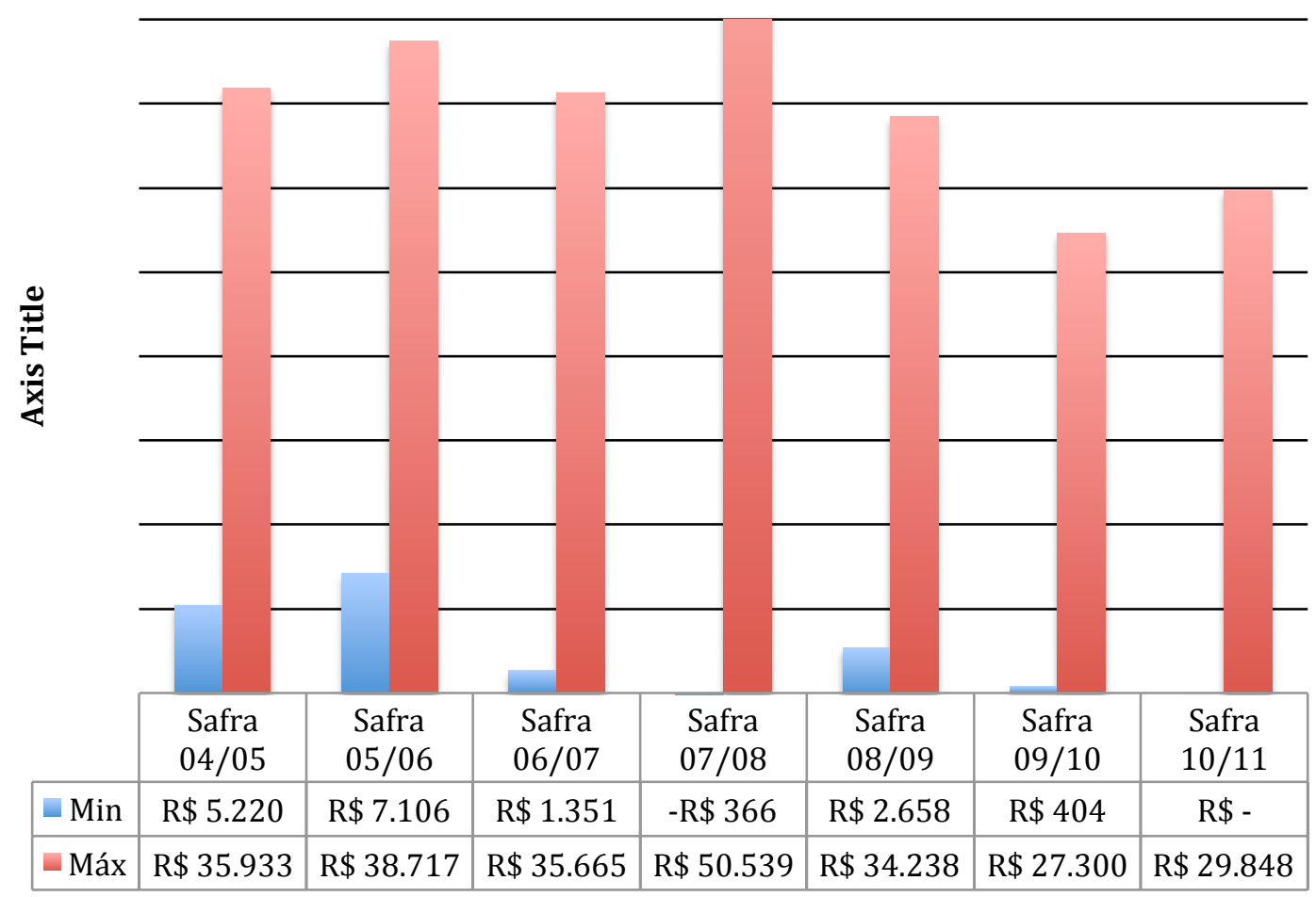

Fonte: ITESP, 2011. Org. BELLACOSA, Julia. 
Ao longo das safras temos uma diferença bastante significativa sobre a renda recebida pelas diversas famílias. $\mathrm{Na}$ safra 2004/2005 aquele que mais recebeu pela produção obteve a quantia de $\mathrm{R} \$ 35.000$ e o que menos recebeu adquiriu apenas $\mathrm{R} \$ 5.220$. Na safra seguinte, observamos uma variação semelhante entre aquele que mais recebeu e o que menos arrecadou, cujos valores variam de $\mathrm{R} \$ 7.106$ a $\mathrm{R} \$ 38.710$. Entretanto, a diferença mais significativa ocorreu na safra 2007/2008 - período em que uma família obteve renda anual de $\mathrm{R} \$ 50.000$ enquanto outra contraiu dívida de $\mathrm{R} \$ 366,00$ junto à usina.

Com relação à formação de dívidas nesta "parceria" agroindustrial, os dados mostram que se trata de um caso isolado, isto é, apenas uma família teve saldo negativo durante uma safra (2007/2008). Esse resultado possivelmente está ligado à ocorrência de queimada na produção. Durante entrevista de campo, nos foi relatado que uma família do núcleo II do assentamento havia perdido toda a produção de cana por conta de queimada e assim tiveram de arcar com os custos do plantio.

Ainda sobre a renda total líquida ao longo das safras, podemos observar através do gráfico 5 que houve uma queda, cuja curva não ocorre de forma linear - a renda alcançada na safra 2008/2009, por exemplo, é superior ao valor da safra anterior.

Questiona-se: por que a renda caiu? Inúmeras variáveis podem alterar a renda, a começar pelo número de cortes do cultivo. A cana-de-açúcar, uma vez plantada, permanecerá produzindo durante quatro ou cinco anos consecutivamente (podendo atingir em alguns casos até o sétimo e o oitavo corte) quando então a produtividade diminui muito e é feita a reforma do canavial. Esta lavoura recebe o nome de cana-planta, no seu primeiro corte; soca ou segunda folha, no segundo; e, ressoca ou folha de enésima ordem nos demais cortes até a última colheita, completando, assim, o ciclo da cana plantada, quando é feita a renovação do canavial. Trata-se da progressiva perda de produtividade.

Então o ciclo da cana pode ter influenciado na queda do rendimento ao longo das safras. Há também outra variável que pode ter impactado no decréscimo da renda total líquida. Trata-se do repasse do plantio e colheita às usinas. Nas primeiras safras, o contrato firmado entre a usina e os assentados estabelecia trabalho no canavial através do mutirão, o que foi alterado ao longo do tempo. Com a insatisfação do mutirão, grande parte dos assentados optou por delegar à usina as tarefas de plantio e corte da cana, cujo desconto 
correspondeu em média a $35 \%$ do total da produção. Esse fato denota que ao mesmo tempo em que a renda dos assentados diminui, ocorre a apropriação de uma parcela cada vez maior dessa renda pelas usinas.

Cabe também analisar se a queda da renda advinda da cana esteve acompanhada da queda de produtividade:

\section{Gráfico 6 - Produtividade média, mínima e máxima por hectare.}

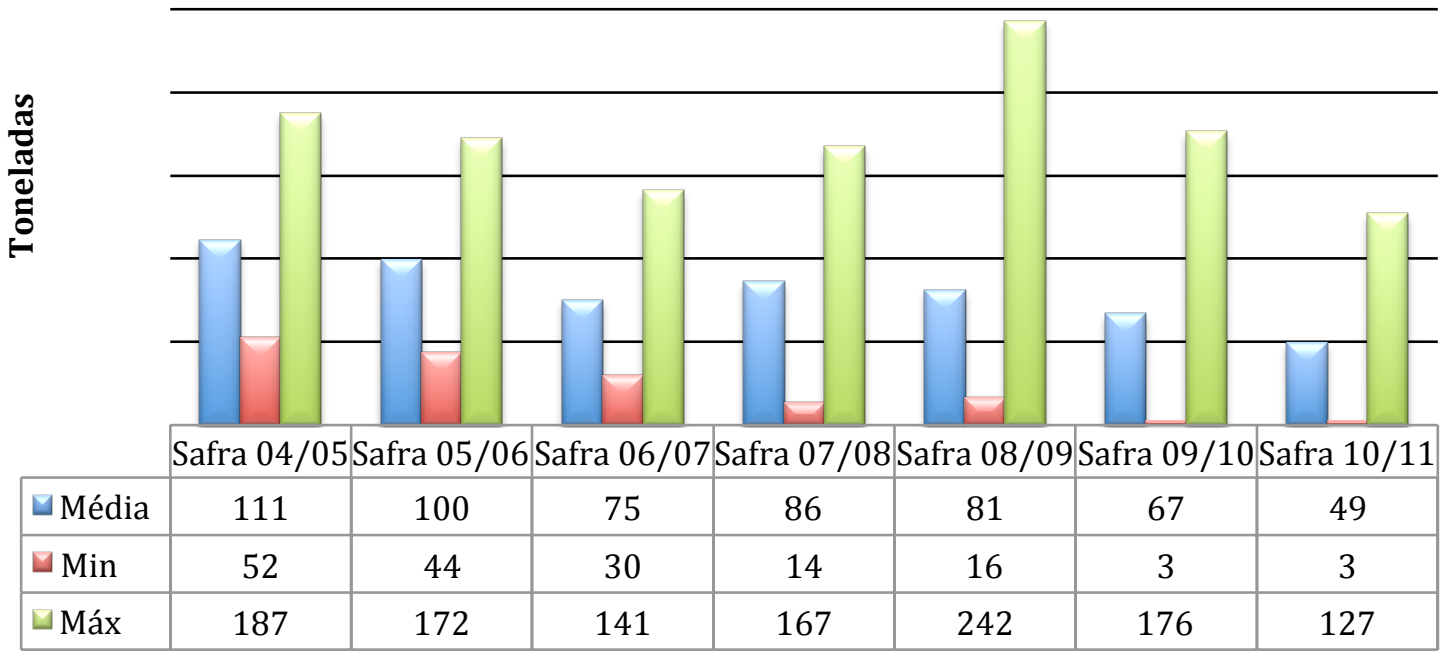

Fonte: ITESP, 2011. Org. BELLACOSA, Julia.

Com relação à média de produtividade de cana de açúcar por hectare, temos uma curva descendente ao longo das safras. Em 2004/2005, a produtividade média de cana no Monte Alegre era de 111 toneladas por hectare. Já na safra seguinte, esse número cai para 100 toneladas, seguido de 75 toneladas em 2006/2007 e 86 em 2007/2008. Já na safra 2010/2011 o valor é de 49 toneladas por hectare - a produtividade mais baixa já verificada. Podemos notar também, conforme Gráfico 6, uma grande diferença de produtividade entre os lotes do assentamento Monte Alegre. Por que isso ocorre? Para os assentados, a quantidade de trabalho despendida no canavial, bem como os investimentos no cultivo são fatores determinantes para o desempenho da produção. Segundo nos contou D. Neusa, moradora do núcleo I, o dinheiro que seria utilizado para adubar a terra foi transferido para comprar comida para a família, o que impactou no crescimento de sua cana: 
"A minha cana deu pra fazer o sexto corte, mas foi bem fraquinha porque não cuidei, porque praticamente fiquei sozinha e os dois últimos anos ficam fracos. E o caminhão de adubo é muito caro, cerca de $\mathrm{R} \$ 3000$, ai tem o calcário, tem o maquinário pra você cultivar. Então vamos supor: se no ultimo ano eu recebi os R $\$ 3000$ com a cana, se eu pago o caminhão, vou comer o que? E os cultivos são que nem a gente, se não se alimentam, ficam fracos. O Moisés teve condições, ele é bem melhor do que a gente. Então ele não precisa se alimentar com o dinheiro daquela cana. Então ele recebeu e aplicou nela mesmo. Ele tem cana até hoje (oitavo corte), a cana dele é boa.“(D. Neusa, núcleo I)

D. Neusa compara o rendimento da sua cana-de-açúcar com o do seu vizinho. Ela reconhece que a cana do Moisés alcançou o oitavo corte devido ao investimento que ele aplicou no cultivo e o trabalho que ele despendeu sobre o mesmo. Ela justifica a diferença no tratamento aplicado à produção pela situação econômica de cada um e pela diferença demográfica familiar. Então aquele que tem uma condição financeira melhor, pode investir mais e obter um resultado mais satisfatório.

É importante destacar que tanto a primeira preparação de solo quanto o plantio inicial são feitos pela usina. Para o restante das safras, a manutenção do cultivo fica a cargo de cada família. A esse respeito, descreve Sr. Domingos:

"O plantio é o seguinte: quando começa no primeiro corte você não vai precisar fazer quase nada, porque já vai vir adubo, o veneno do matamato. Ai no segundo corte, você tem que olhar onde vai nascer braqueara, ai você tem que catar o pé de braqueara, fazer o boca de rua. Depois, ai começa...Se você não tratar, a braqueara toma conta. Se você não tirar a cana fica fininha, e não cresce. Então esse ano, eu e o rapaz estamos cuidando. Ai depois que passou a máquina, cultivou e passou o adubo, nós vamos passar com a bomba de veneno, passa no meio da "rua" toda. A usina só faz o plantio inicial e o corte, e nós fazemos a condução da cultura." (Sr. Domingos, núcleo II)

O impacto da condução dos tratos culturais sobre o resultado final da produção também é compartilhado por outros assentados:

"O ano retrasado tinha uns dois lotes ali. O cara não tratou, comprou veneno e não passou, não carpiu, não limpou. A cana sumiu na braqueara. Ai quando vieram para trazer o contrato, eu falei: esses dois contratos aqui leva de volta porque não tem cana pra cortar. Mas que nem aconteceu com a Toninha e o João Careca. A cana morreu no mato. Quer dizer, o cara nem no sítio pára, nem fica aqui, o mato foi crescendo e tomou conta. 
Ele comprou um monte de veneno, pagou caro, e o veneno ficou lá estragando, preguiça de passar." (Sr. Domingos, núcleo II)

"Se fizer lá direitinho, se estiver sempre cuidando com adubo, calcário, ai a cana vai longe." (Moisés, núcleo I)

"Quem trata bastante da cana pega mais dinheiro de quem não zela bem." (Sr. Artur, núcleo I)

Outro ponto a ser levado em conta no tocante à diferença de produtividade da cana por lote refere-se ao fato de que os assentados ficam à mercê da usina em todo o processo produtivo, inclusive sobre o cálculo da produtividade e do lucro. De acordo com Ferrante (2009, p.143), sobre essas variações recaem o peso do cuidado dado pelos assentados à cana em seus lotes, certamente, mas também crescem as desconfianças que os assentados têm sobre os insumos, o transporte e a pesagem, já que durante uma mesma safra, a renda de assentados que plantaram no mesmo período, na mesma área, varia muito, conforme trecho:

"Há outros elementos a considerar nessa trama, entre eles, a relação de compadrio que alguns assentados têm com usineiros, o que por vezes os beneficia na hora de "pegar o cheque". Existem assentados que parecem ser um tipo de representante da usina na parceria, eles controlam as turmas de trabalho que plantam e colhem a cana, as horas de máquinas na preparação da terra. Geralmente alguns deles têm uma antiga relação de trabalho com a usina ou até são funcionários dela. Depoimentos de alguns assentados indicam sua desconfiança diante do fato de terem conseguido alta renda com a cana, enquanto alguns outros estão em endividamento progressivo."

O preço para o pagamento da cana tem sido feito com base no valor do ATR (Açúcar Total Recuperável) divulgado pelo CONSECANA-SP (Conselho dos Produtores de Cana-de-Açúcar e Álcool do Estado de São Paulo) no mês da entrega da safra. Para o cálculo, a maioria das usinas utiliza a média do ATR apurado em conjunto de todos os lotes do Assentamento Monte Alegre em detrimento do ATR individual - o que dificulta o entendimento sobre as variáveis da renda entre as famílias.

Este fato reforça a relação assimétrica de poder que envolve a "parceria" entre o assentado e a usina, cujo primeiro se encontra em relação de subordinação frente à usina 
não somente ao que tange o processo produtivo, mas também em relação à renda anual obtida.

\section{O que foi feito com a renda da cana?}

Conforme descrevemos anteriormente, as famílias obtiveram um rendimento expressivo com o cultivo da cana. Se compararmos a renda obtida na produção da cana nesse período e a renda adquirida anteriormente através do plantio de outras culturas, observaremos que a primeira alcançou resultados muito mais notórios sobre esse viés econômico. Então em meio a um cenário de escassez de recursos, a cana aparece como salvação;

"Nem sei se ia existir eu e neto aqui hoje não...Porque onde a gente ia tirar comida? Quando eu estava desanimada, saiu a história da cana, ai deu certo.” (D. Neusa, núcleo I)

Não há números oficiais sobre a renda obtida com outras culturas anteriores à parceria agroindustrial canavieira. Os dados que temos a esse respeito foram colhidos durante depoimentos obtidos em trabalhos de campo na região, pelo período de dois anos.

De fato, conforme referenciamos anteriormente, até os que falavam com reservas sobre o ingresso da cana no assentamento afirmam que do ponto de vista econômico, a cana trouxe muitos benefícios à região. Um dos elementos que sustentam essa afirmação é a mudança no padrão de habitação do assentamento. No período que antecedeu o advento da cana, as casas eram mais simples, menores, sem acabamento, algumas sem forro ou sem piso.

A renda obtida através da produção canavieira foi, na maioria dos casos, utilizada para ampliar e reformar a moradia:

"A cana foi muito boa para nós. Eu mesmo, nessa casa, todo mundo me conhece. Estou há 26 anos aqui no assentamento, essa casa era bem pequeninninha, bem apertadinha. Dá até para ver a divisa se olhar direito: olha o tamanho que era o meu quarto. Não tinha laje, era uma casinha bem humilde mesmo. Ai quando plantei a cana, no primeiro ano eu reformei a casa. No segundo ano eu comprei aquele carro gol. Na época eu paguei 12.800 reais a vista, tudo dinheiro da cana."(Moises, núcleo I) 
Moisés afirma que a renda obtida com a cana foi utilizada também para comprar um automóvel. Assim como ele, muitos adquiriram um carro com a renda da cana:

\footnotetext{
"Não teve um que não gostou da cana. Teve o que carpiu, o que não carpiu, o que zelou, o que não zelou, mas todo mundo gostou da cana. Quem não tinha seu carrinho comprou. Quase todos compraram seu carrinho, e ajudou bastante, não ajudou? Eu comprei também um carrinho usado." (Sr. Artur, núcleo I)
}

Além da aquisição do automóvel e de benfeitorias nos lotes, a renda obtida com a cana foi muito utilizada também para quitar dívidas junto às instituições financeiras. A esse respeito é importante destacar que de forma bastante controversa, as usinas passam a ser vistas pelos assentados como entidades generosas, acolhedoras, que, diferentemente das instituições bancárias, não selecionam seus "clientes/parceiros" pelas condições socioeconômicas. Então, com ou sem dívidas, todos puderam se tornar "parceiros", conforme destacado no trecho:

"Antigamente, a gente plantava tudo financiado. Ai chegava na hora a gente colhia e não conseguia cobrir as dívidas. Ficávamos endividados, e foi aí aonde a cana deu certo, porque o pessoal não conseguia mais crédito porque estava com nome sujo, não conseguia um outro financiamento. Ficava pendente no Serasa e SPC, porque não pagou a conta. Então a cana surgiu em uma hora boa para nós, porque uns $80 \%$ estava com nome no Serasa e SPC e conseguiu plantar a cana. A usina não olhou para esse lado: ela entrou, fez o investimento, foi descontando em 3 vezes, e o pessoal foi pagando as dívidas. A cana foi um ótimo negócio para a gente no assentamento.” (Sr. Luiz Pereira, núcleo I)

Na visão do Sr. Luiz Pereira, o contrato de "parceria" possibilitou aos assentados uma nova oportunidade para produzir, ao mesmo tempo em que representou a liberdade frente às amarras das instituições financeiras. Nesse caso, a usina é colocada como uma entidade "parceira" que fornece os meios para o assentado produzir. Essa visão encontra respaldo no esgotamento e na falta de continuidade de políticas públicas dirigidas ao assentamento. Conforme afirmam Ferrante e Amaral (2007, p.110), a proposta de consórcio com as usinas da região surge e ganha força justamente num momento de "vazio" político-institucional no interior destes assentamentos.

Diante desse cenário questiona-se: além da aquisição de bens e pagamento de dívidas, a renda da cana foi utilizada para outros fins? Mais especificamente: ela foi 
utilizada como base de investimento em outras culturas? Os assentados diversificaram a produção ou tornaram-se totalmente dependentes da produção canavieira?

Para apoiar essa análise montamos uma tabela a partir do depoimento de oito famílias que foram escolhidas de forma aleatória entre os núcleos I e II do assentamento Monte Alegre. Por uma questão de ética, os nomes das famílias não foram descriminados. As informações apresentadas destacam o número de safras em que cada família participou do cultivo; a renda líquida obtida em todo esse período; a média da renda líquida por safra; e por último o que foi feito com a renda da cana.

Conforme podemos visualizar na tabela abaixo, a renda média por safra obtida por essas famílias variou de R\$ 13.780 a $\mathrm{R} \$ 26.360$ - o que lhes permitiu alcançar até $\mathrm{R} \$ 184.520$ com o cultivo da cana nesse primeiro ciclo de plantio - o que representou, de fato, uma quantia bastante significativa.

\section{Tabela 1 - Balanço socioeconômico do cultivo da cana no assentamento}

\begin{tabular}{|c|c|c|c|c|c|c|c|}
\hline \multicolumn{8}{|c|}{ Balanço socioeconômico do cultivo da cana no assentamento } \\
\hline Familia & Núcleo & $\begin{array}{l}\mathrm{N}^{0} \text { de } \\
\text { safras }\end{array}$ & Ren & $\begin{array}{l}\text { total no } \\
\text { íodo }\end{array}$ & & $\begin{array}{l}\text { ia por } \\
\text { fra }\end{array}$ & O que foi feito com a renda? \\
\hline $\mathbf{A}$ & 1 & 5 & $\mathrm{R} \$$ & 106.746 & & 21.349 & Ampliou e reformou a casa, comprou um carro. \\
\hline B & 1 & 7 & $\mathrm{R} \$$ & 119.870 & & 17.124 & $\begin{array}{l}\text { Pagou dívidas no banco, construiu a casa, } \\
\text { comprou um carro, e guardou parte do dinheiro } \\
\text { que vai tirando aos poucos para garantir o } \\
\text { sustento da família. }\end{array}$ \\
\hline $\mathbf{C}$ & 2 & 3 & $\mathrm{R} \$$ & 41.340 & & 13.780 & $\begin{array}{l}\text { Pagou dívidas no banco, comprou adubo e } \\
\text { investiu no gado. }\end{array}$ \\
\hline $\mathbf{D}$ & 1 & 7 & $\mathrm{R} \$$ & 145.007 & $\mathrm{R} \$$ & 20.715 & $\begin{array}{l}\text { Pagou dívidas no banco de } 15 \text { anos atrás, } \\
\text { ampliou e reformou a casa, investiu em outras } \\
\text { culturas (comprou } 150 \text { mudas de manga e } \\
\text { mexerica). Espera renovar o canavial para } \\
\text { formar um pomar e uma granja nos outros } 50 \% \\
\text { do lote, e assim trazer os filhos de volta ao } \\
\text { assentamento. }\end{array}$ \\
\hline $\mathbf{E}$ & 1 & 7 & $\mathrm{R} \$$ & 184.520 & $\mathrm{R} \$$ & 26.360 & $\begin{array}{l}\text { Ampliou e reformou a casa, comprou } \\
\text { eletrodomésticos, construiu uma pequena } \\
\text { piscina, comprou um carro, investiu nos outros } \\
50 \% \text { do lote, no plantio de grãos e frutas. }\end{array}$ \\
\hline $\mathbf{F}$ & 2 & 3 & $\mathrm{R} \$$ & 51.832 & $\mathrm{R} \$$ & 17.277 & $\begin{array}{l}\text { Pagou dívidas no banco, ampliou e reformou a } \\
\text { casa, investiu na produção de leite. }\end{array}$ \\
\hline
\end{tabular}




\begin{tabular}{|c|c|c|c|cc|l|l|} 
G & 1 & 4 & $\mathrm{R} \$$ & 76.751 & $\mathrm{R} \$ 19.188$ & $\begin{array}{l}\text { Pagou dívidas no banco, reformou a casa } \\
\text { (colocou piso, forro), comprou um carro, } \\
\text { investiu na cana e em outras culturas como } \\
\text { milho e manga. }\end{array}$ \\
\hline H & 2 & 4 & $\mathrm{R} \$$ & 60.102 & $\mathrm{R} \$$ & 15.026 & Pagou dívidas no banco. \\
\hline
\end{tabular}

Com relação ao que foi feito com essa renda: grande parte das famílias pagaram dívidas junto às instituições financeiras, ampliaram e reformaram a casa, aplicaram uma parcela no cultivo da mesma cana, e também investiram em outras culturas nos outros 50\% do lote, com destaque para o plantio de grãos, frutas, criação de gado e produção de leite.

Nesse sentido, ao possibilitar o pagamento das dívidas, e o investimento em outros cultivos, antes paralisados por falta de financiamento, a monocultura canavieira, contraditoriamente, pode ter favorecido a permanência do camponês na terra e, de certa forma, sua sociabilização no interior do assentamento.

Esse movimento ocorre de forma dialética, pois essa atividade representa uma ameaça à autonomia camponesa, à continuidade do trabalho familiar e, em muitos casos, simboliza um obstáculo à sociabilização do camponês no assentamento, já que a cana é excludente de mão-de-obra.

Na visão de Jair $^{6}$, as pessoas obtiveram melhorias em termos socioeconômicos, mas não criaram raízes, o que se configuraria em uma "falsa" permanência do camponês na terra, ou uma permanência "temporária":

"Então é o seguinte: alguns fizeram plantios perenes, outras fizeram horta, mas muitos se tornaram dependentes da cana e não criaram raízes. Quer dizer, acabando a cana hoje, muitos voltarão à estaca zero, porque não tem um projeto para dar continuidade. A maioria foi gastando, melhorando casa, comprando carro, televisão, e isso é importante também.” (Jair, núcleo II)

Jair destaca que, ao produzir cana, muitos assentados deixaram de lado suas antigas atividades: as pessoas acabaram tirando tudo que tinham, tiraram cerca, tiraram pasto, tiraram tudo e começaram uma nova atividade. Muitos assentados acabaram ficando na dependência da produção canavieira.

\footnotetext{
${ }^{6}$ Jair dos Santos é assentado do núcleo II do Monte Alegre e atual Secretário de Desenvolvimento Econômico, Agricultura e Meio-Ambiente de Motuca.
} 
Há também os que afirmam que a "parceria" agroindustrial através do plantio de cana desmobilizou politicamente a organização dos assentados, conforme a fala de Élio Neves, presidente do sindicato rural fundador do assentamento:

\begin{abstract}
"Já faz mais de um ano que nós estamos sendo demandados pelos assentados para rediscutir o processo de desenvolvimento dentro do assentamento, inclusive a cana. É quase que aquilo que antes, durante esse tempo em que a cana foi vendida como o canto das sereias, fazia dos assentados adversário frontal do sindicato que nós dirigimos e que é fundador do assentamento. Então os assentados viraram oposição ao sindicato e agora eles querem voltar para casa."
\end{abstract}

Élio se refere ao momento atual do projeto cana no assentamento, cuja renovação dos canaviais permanece incerta, já que as usinas não têm demonstrado interesse em renovar os contratos. Isso tem sido motivo de muita preocupação para os assentados que tem procurado apoio do sindicato rural para intermediar um novo diálogo com as usinas. Esse fato denota certa dependência em torno do projeto agroindustrial, cujo reflexo está presente na contraditória incorporação do campesinato às dinâmicas produtivas do capital nacional e transnacional que atua no setor de agrocombustível. A dependência que se criou é na verdade reflexo da subordinação dos camponeses nesta cadeia produtiva, comandada pela lógica capitalista, que visa sobretudo a acumulação desenfreada de capital, onde o camponês é visto de forma vantajosa em alguns momentos e, repentinamente, não é mais atrativo.

\title{
Considerações Finais
}

A implantação do projeto agroindustrial da cana no assentamento Monte Alegre significou para muitos assentados uma forma de sobrevivência na terra, que passou a ser vista como "salvação". Assim como também representou um marco histórico, um divisor de águas no imaginário dos moradores do assentamento: o antes (a luta, o sofrimento) e o depois da monocultura (finalmente a conquista):

"Eu fiquei acampado em Pradópolis. Eu trabalhava na Usina São Martinho, eu cortava cana. (...) Foi sofrido demais aquela época e com muita luta nós conseguimos chegar até aqui porque naquele tempo nós não tinha condição, nós lutamos, dividiu as terras pra cada um, lote de 6 
alqueires, daí plantamos lavoura. Sempre que plantávamos lavoura, não dava muito não. $\mathrm{E}$ ai chegou um momento... agora, há pouco tempo, que teve um plano ai do plantio de cana e melhorou pra todo mundo. Se não fosse a cana, o povo não agüentava ficar aqui."(Sr. Fagundes)

A usina passa então a ser vista como uma organização "parceira" que se propõe a ajudar sem olhar a condição socioeconômica de cada um, o que os liberta das amarras das instituições financeiras que os impede de continuar a produzir. Essa controversa interpretação encontra respaldo na falta de políticas públicas direcionadas ao assentamento. A cana-de-açúcar, por sua vez, se materializa como monocultura, substituindo parcelas do território antes ocupadas com culturas de primeira necessidade.

Conforme vimos, o primeiro ciclo de cultivo da cana no assentamento trouxe uma renda bastante expressiva para a maioria dos moradores da fazenda Monte Alegre, e foi utilizada principalmente como investimento em outras culturas, para pagar dívidas, ampliar e reformar a casa, além de ser utilizada na compra de bens materiais, como automóvel, eletrodomésticos, etc. Nesse sentido, a cana através da parceria agroindustrial pode ter favorecido a permanência do camponês na terra, e sua sociabilização no interior do processo produtivo, mesmo que de forma temporária.

Dessa forma, apesar da cana não favorecer o trabalho familiar, a renda advinda de sua produção pode ter propiciado trabalho no lote, no momento em que se investiu em outros cultivos. Esse pensamento mostra sinergia com a fala do Sr. Luiz Pereira, morador antigo do Monte Alegre I:

"Nós estamos aqui há 26 anos. Depois que acabaram os 5 anos de cana, meus filhos foram obrigados a sair pra fora, para ir trabalhar, porque ai da um fracasso danado, porque nós teríamos que ter pelo menos uma arrancada de reforma de cana para que tivéssemos resultado para investir em outras coisas. Se você olhar ali, eu tenho 600 telhas, que era para fazer um barracão de frango de corte. Só que na hora que eu cheguei no banco do Brasil para obter financiamento, eles negaram. Então, a telha nos compramos com o dinheiro um pouco da Usina que meus filhos trabalhavam e um pouco daqui. Então temos uns 90 pliares la embaixo, mas não vai dar para construir o barracão porque não vai ter dinheiro, isso se não plantar cana. Agora se plantar...Hoje meus 3 filhos homem estão em Araçatuba trabalhando. Dois são operadores de caldeira, e o outro trabalha na fabricação de açúcar. Eles ficam ligando toda a semana para saber se vamos ou não plantar cana. Por que se não for plantar cana, eles não vem pra cá, porque não tem serviço pra eles fazerem. O que tem aqui, eu e a mulher damos conta.’(Sr.Luiz Pereira, núcleo I) 
Em estado de descapitalização, a família ficou bastante limitada para investir em outros cultivos no lote. De acordo com Sr. Luiz, após o término das cinco safras de cana, os filhos foram obrigados a deixar o assentamento para trabalhar fora da unidade familiar, já que não havia mais trabalho para eles na terra. A preocupação do Sr. Luiz em ter trabalho para a família no lote sinaliza que não se trata aqui da busca desenfreada pela obtenção de lucro, mas da busca pela reprodução do grupo familiar. Como resposta adaptativa à crise instaurada, os filhos do Sr. Luiz recorreram ao trabalho acessório não agrícola e à migração - fato que a princípio não os descaracteriza enquanto camponeses.

A cana nesse caso aparece também como uma estratégia de sobrevivência na terra, e como uma forma de sociabilização do camponês no processo produtivo, uma vez que o cultivo seria o responsável por trazer os filhos de Luiz Pereira de volta à terra e ao seio familiar. Neste sentido, a produção de cana seria uma alternativa encontrada para a obtenção da renda necessária para investir na produção de frango.

Logo, o campesinato brasileiro permanece e se reproduz através das contradições do capital e com os meios que possui, seja através da luta pela terra, seja pela sujeição de sua renda ou pelo trabalho não camponês. Conforme descreve Shanin, a resposta do campesinato às situações de crise nas quais eles são submetidos é, sobretudo, complexa:

“(...) as comunidades camponesas demonstram uma real habilidade para se ajustar a novas condições e também uma grande flexibilidade para encontrar novas formas de se adaptar e ganhar a vida. Em alguns lugares, há comunidades de camponeses que hoje vivem principalmente do turismo. Há lugares onde as comunidades camponesas ganham a vida com novos métodos de produção e, em outros, os camponeses ganham a vida por meio da combinação do trabalho camponês e do trabalho não camponês." (Shanin, 2008, p. 25)

Este limiar entre indícios de descamponização e estratégias de resistência compõe uma linha tênue. Se procurarmos uma realidade fixa, não vamos encontrar isso no campesinato. $\mathrm{O}$ assentamento Monte Alegre sinaliza essa pluralidade, que se traduz no processo contraditório de recriação do campesinato, conforme observamos. De fato, a existência camponesa deve ser vista em suas expressões contraditórias, que pressupõem a diferenciação interna, mostrando assim que os camponeses não são puros, mas sujeitos que podem enriquecer-se e aburguesar-se. Por outro lado, também podem enriquecer-se sem deixar de ser camponeses (PAULINO, 2007, p. 349). 


\section{Referências Bibliográficas}

AMARAL, D. T.; FERRANTE, V. L. S. B. Assentamento rurais e desenvolvimento local: produção comercial de cana em parcerias com a agroindústria. In: Raízes. Vol. 26, $\mathrm{N}^{\circ}$ s 1 e 2, Jan-Dez, 2007.

CPT (Comissão Pastoral da Terra). Agroenergia: Mitos e Impactos na América Latina. São Paulo, 2007.

D’AQUINO, T. A casa, os sítios e as Agrovilas: uma porética do tempo e do espaço o assentamento das terras de promissão. In: Encontro da ANPOCS, XX, 1996. Caxambu, 35p. (Mimeo.)

FABRINI, J. E. O campesinato frente à expansão do agronegócio e do agrocombustível. In: SAQUE, M. A e SANTOS, R. A. (org). Geografia Agrária, território e desenvolvimento. São Paulo: Expressão Popular, 2010.

FERRANTE, V. L. S. B. Os herdeiros da modernização: grilhões e lutas dos boias-frias. Revista São Paulo em Perspectiva, v. 8, n. 3, jun-set. São Paulo: Fundação Seade, 1994.

. Assentamentos rurais no território da cana: controvérsias em cena. In: Revista Nera, Ano 10, nº 11, 2007.

; ALMEIDA, L. M. M. C. Assentamentos rurais como celeiros da cana. Por onde caminha a reforma agrária? In: Ruris, Vol. 3, nº 1, 2009.

IBGE - Instituto Brasileiro de Geografia e Estatística. Censo demográfico 2010: resultados preliminares - São Paulo.

ITESP - Instituto de Terras do Estado de São Paulo

MARTINS, J. S. O cativeiro da terra. São Paulo: Hucitec, 1986.

MOURA, M. M. Camponeses. São Paulo: Editora Ática, 1986.

OLIVEIRA, A. U. Agricultura e Indústria no Brasil. In: Boletim Paulista de Geografia, $n^{\circ}$ 58, São Paulo: AGB, 1981. 
. Modo de Produção Capitalista e Agricultura. São Paulo: Ática, 1986. . Agricultura Camponesa no Brasil. São Paulo: Contexto, 1990.

Agricultura Brasileira Transformações Recentes. In: ROSS. J. L. S. (Org.), Geografia do Brasil. 4. ed. 1. Reimpr. São Paulo: Edusp, 2003a.

. A geografia agrária e as transformações territoriais recentes no campo brasileiro. In: Novos caminhos da geografia. São Paulo: Contexto, 2007.

PAULINO, E. T. Geografia Agrária e Questão Agrária. In: FERNANDES, B.M; MARQUES, M.I.M; SUZUKI, J. C (org). Geografia Agrária: teoria e poder. São Paulo: Expressão Popular, 2007.

PAULINO, E. T; ALMEIDA, R. A. Terra e território: a questão camponesa no capitalismo. São Paulo: Expressão Popular, 2010.

PORTARIA ITESP - 75, de 24-10-2002 - Diário Oficial do Estado - Fundação Instituto de Terras do Estado de São Paulo "José Gomes da Silva”, 2002.

PORTARIA ITESP - 77, de 2004 - Diário Oficial do Estado - Fundação Instituto de Terras do Estado de São Paulo "José Gomes da Silva”, 2004.

SHANIN, Teodor. Lições Camponesas. In: PAULINO. Eliane. T., FABRINI, João. E. (Orgs). Campesinato e territórios em disputa. São Paulo: Expressão Popular, 2008.

STETTER, E. A. A trajetória da cana no assentamento Monte Alegre. In: FERRANTE, V. L. S. B. (org) Retratos de Assentamentos, nº 09.UNIARA/UNESP, 2004. 